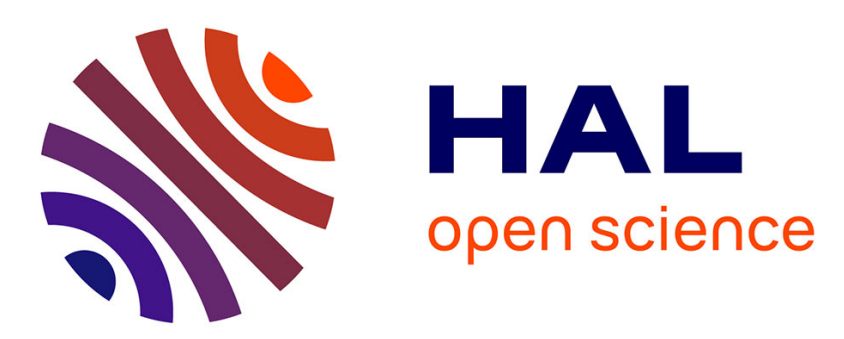

\title{
Elevated non-esterified fatty acid and $\beta$-hydroxybutyrate in transition dairy cows and their association with reproductive performance and disorders: A meta-analysis
}

Amine Abdelli, Didier Raboisson, Belabdi Ibrahim, Amer Kalem, Rachid

Kaidi, Mokrane Iguer-Ouada

\section{To cite this version:}

Amine Abdelli, Didier Raboisson, Belabdi Ibrahim, Amer Kalem, Rachid Kaidi, et al.. Elevated non-esterified fatty acid and $\beta$-hydroxybutyrate in transition dairy cows and their association with reproductive performance and disorders: A meta-analysis. Theriogenology, 2017, in press, 10.1016/j.theriogenology.2017.01.030 . hal-01607365

\section{HAL Id: hal-01607365 \\ https://hal.science/hal-01607365}

Submitted on 26 May 2020

HAL is a multi-disciplinary open access archive for the deposit and dissemination of scientific research documents, whether they are published or not. The documents may come from teaching and research institutions in France or abroad, or from public or private research centers.
L'archive ouverte pluridisciplinaire HAL, est destinée au dépôt et à la diffusion de documents scientifiques de niveau recherche, publiés ou non, émanant des établissements d'enseignement et de recherche français ou étrangers, des laboratoires publics ou privés. 


\section{Accepted Manuscript}

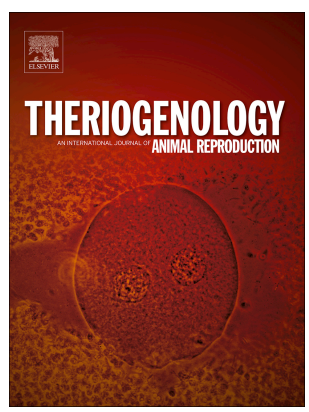

Elevated non-esterified fatty acid and $\beta$-hydroxybutyrate in transition dairy cows and their association with reproductive performance and disorders: A meta-analysis

Amine Abdelli, Didier Raboisson, Belabdi Ibrahim, Amer Kalem, Rachid Kaidi, Mokrane Iguer-Ouada

PII: S0093-691X(17)30041-9

DOI: 10.1016/j.theriogenology.2017.01.030

Reference: THE 13985

To appear in: Theriogenology

Received Date: 23 September 2016

Revised Date: 16 January 2017

Accepted Date: 16 January 2017

Please cite this article as: Abdelli A, Raboisson D, Ibrahim B, Kalem A, Kaidi R, Iguer-Ouada M, Elevated non-esterified fatty acid and $\beta$-hydroxybutyrate in transition dairy cows and their association with reproductive performance and disorders: A meta-analysis, Theriogenology (2017), doi: 10.1016/ j.theriogenology.2017.01.030.

This is a PDF file of an unedited manuscript that has been accepted for publication. As a service to our customers we are providing this early version of the manuscript. The manuscript will undergo copyediting, typesetting, and review of the resulting proof before it is published in its final form. Please note that during the production process errors may be discovered which could affect the content, and all legal disclaimers that apply to the journal pertain. 
Revised

\title{
Elevated non-esterified fatty acid and $\beta$-hydroxybutyrate in
}

\section{transition dairy cows and their association with reproductive}

\section{performance and disorders: a meta-analysis}

\author{
Amine Abdelli ${ }^{1,2}$, Didier Raboisson ${ }^{3 *}$, Ibrahim Belabdi ${ }^{1,2}$, Amer Kalem ${ }^{1,2}$, Rachid \\ Kaidi $^{1,2}$, Mokrane Iguer-Ouada ${ }^{4}$ \\ ${ }^{1}$ Institut des Sciences Vétérinaires-Blida. \\ ${ }^{2}$ Laboratoire des Biotechnologies liée à la Reproduction Animale (LBRA), Université SAAD \\ DAHLAB, BP-270 Blida (09000). \\ ${ }^{3}$ IHAP, Université de Toulouse, INRA, ENVT, Toulouse, France. \\ ${ }^{4}$ Faculté de biologie, université de Béjaia. \\ *Corresponding author : D. Raboisson
}

Ecole Nationale Vétérinaire de Toulouse (ENVT), UMR 1225, Interaction Hôte Agent Pathogène (IHAP), F-31076 Toulouse, France

Email: $\underline{\text { d.raboisson@envt.fr }}$

Tel: +33 561 193230; Fax: +33561193924

\section{Abstract}

A meta-analysis including 36 different results of statistic models from 14 papers was conducted. It evaluated the association between elevated non-esterified fatty acids and/or $\beta$ hydroxybutyrate (BHB) on the reproduction outcomes that were pregnancy at first insemination, estrous cyclicity, time to pregnancy, metritis and placental retention. Each association between BHB or NEFA and an outcome reported in literature was a model considered as raw-data for the meta-regression. For each outcome, the meta-regression adjusted the odds ratio, relative risk or hazard ratio with various moderators to reduce the 
heterogeneity among the studies. The relative risk for metritis and placental retention in case of high BHB or NEFA was in accordance to previous meta-regression and was 1.91 (IC95 = 1.72 to 2.12$)$ and $1.51(95 \% \mathrm{CI}=1.19$ to 1.92$)$, respectively. The relative risk for pregnancy at first insemination in case of high $\mathrm{BHB}$ was assessed to be $0,62(95 \% \mathrm{CI}=0,41$ to 0,93$)$. The hazard ratio for time to pregnancy in case of high $\mathrm{BHB}$ and NEFA was $0.77(95 \% \mathrm{CI}=0.61$ to 0.97). The present meta-analysis failed to clearly conclude on the association between estrus cyclicity and high BHB or NEFA. The present work allowed a new overview on the association between hyperketonemia and reproductive performance and disorders. It updated the previous meta-regression and included new outcomes. It highlighted the urgent need of further intensive epidemiologic studies on this topic.

Key words: NEFA; BHBA; dairy cattle; meta-analysis; reproduction.

\section{Introduction}

During early lactation, high yielding dairy cows are unable to meet their tremendous energy demand by the mammary gland from dietary intake alone [1]. The cows must accommodate this increase in energy demand by fat mobilization from adipose tissue to provide non esterified fatty acids (NEFA) as an energy fuel [2-3]. Excessive fat mobilization leads to increased concentration of NEFA in the blood. NEFA can partly be used by final tissus but the main part is metabolised by hepatocytes via $\beta$-oxidation to acetyl-coenzyme A (AcetylCoA). Acetyl-CoA is also shunted to de novo cholesterol synthesis [4] or may be metabolised into ketones. Circulating ketone bodies can be used to a certain extent as a fuel source by heart, brain, liver, and mammary tissue [5], but too much ketogenesis and low tissus uptake may result in increasing circulating ketone bodies and occasionally hyperketonemia [6]. $\beta$ hydroxybutyrate (BHB) is the predominant circulating ketone body in ruminants [7] and is 
considered a gold standard for diagnosing sub-clinical ketosis (SCK) due to its stability in blood [8]. Nonetheless, NEFA can also be used as markers of negative energy balance [9-10]. In the last years, many studies have shown that increased concentrations of BHB or NEFA are associated with various illness including reproductive disorders such as placental retention, metritis, endometritis, purulent vaginal discharge, delayed cyclicity, decreased conception at service ... [11-12-13-14-15-16-17-18-19-20-21-22]. Amazingly, the associations between increased concentrations of BHB or NEFA and reproductive disorders remain inconsistent and the overall positive or negative association is still difficult to evaluate [9]. Some possible explanations for the inconsistency between the results of individual studies are the heterogeneity of the design, how the trials have conducted and the heterogeneity of the enrolled populations.

A recent meta-analysis [23] was performed on disorders associated to hyperketonaemia, but there remains some issues to be fixed. First, the precision of the effect size (i.e. the risk for disorder in case of SCK) depended on the outcomes. It was reported to be good for disorders such as abomasum displacement, early culling or placental retention but the authors of the previous meta-analysis clearly highlighted the limits of some outcomes related to reproduction due to a low number of papers available for the meta-regression. Second, the previous meta-analysis adjusted the effect size on several co-variables including BHB or NEFA thresholds, but did not distinguish whether NEFA or BHB were used to define SCK. Third, outcomes like estrous cyclicity and time to pregnancy were not included in the previous meta-analysis although they are key parameters for reproduction management. Fourth, (few) new papers reporting the association between high BHB or NEFA concentrations and reproductive disorders are available since the previous has been done and analysing how they impact the previous results may be useful. The present work aims to extend the above mentioned work [23] for reproductive performance and disorders, thanks to 
a new meta-analysis with updated literature, new reproductive parameters and new way to adjust for co-variables and definition of SCK.

\section{Materials and methods}

\subsection{Literature search and selection of papers}

All English-language papers published between 1980 and June 2016 that analyzed the association of elevated NEFA and BHB in early lactation and productive and reproductive performance were included. The search was carried out using PubMed (the National Library of Medicine, Bethesda, MD, USA; http://www.ncbi.nlm.nih.gov/pubmed/), CAB (CAB Abstracts, Cab International, Oxon, UK; http://cabi.org/), and Google Scholar (CompanyGoogle, California, USA; http://scholar.google.com/). The following key words in different combinations were used for the search: BHB, NEFA, subclinical ketosis, fertility, conception, calving rate, peri-partum, reproductive performance, reproduction, cow, early lactation and reproductive disorders. To be included in the data set, the papers must have examined the effect of elevated NEFA and/or BHB on reproductive performance and disorders (named outcomes) in peri-partum dairy cows. The papers were excluded from the meta-analysis in cases of (i) no original research papers published in a peer-reviewed journal, (ii) no study design described, (iii) risk not calculable thanks to the results of the paper (e.g., relationship only measured by correlation coefficient), (iv) lack of disease-free controls and association estimated by comparing cases according to severity, (v) analyses carried out at the herd level and (vi) data collected from countries with traditionally non intensive dairy farming (Table S1).

\subsection{Data organization and abstracting}


The literature review process ultimately identified 48 studies, of which 34 were considered unsuitable for inclusion. 36 different results of statistical models out of the 14 remaining studies were extracted. Each result of model was included in the database (one line of the database per model) which contains the type of study (observational and clinical trials), the country, the number of cows and herds studied, the average $305 \mathrm{~d}$ milk production, the statistical method used (logistic regression, Poisson regression, or raw data with contingency table), the expression of risk [odd ratio (OR), relative risk (RR) and hazard ratio (HR)], the metabolite used for the diagnose (BHB and NEFA), the threshold used, the peripartum week of sampling, the total number of samplings per cow, the prevalence of the outcome or of the mean value if relevant, the mean, standard error or standard deviation value of the risk or the change in the outcome and its $95 \%$ confidence interval. Because HR, OR or RR were used in the various analyses, the term "risk" refers to any of these terms when at least 2 of them were used in the meta-regression.

\subsection{Meta-Analysis Procedures}

All the analyses were computed in R [24] by using the Meta [25] and Metafor [26] statistical packages. For easier interpretation, the logarithmic-scale observed outcomes in the metaregression has been transformed back to the risk scale through exponentiation [27]. A fixedeffects model was first used. In this model, it was assumed that the true effect sizes were the same for all studies and any difference observed was simply due to sampling variation. A random-effects model was then conducted for each metabolite to estimate the logarithmic effect size, its $95 \%$ confidence interval, and its statistical significance ( $\mathrm{p}$ value). The inconsistency of results among trials was quantified using both $\chi 2$ test of heterogeneity (Cochran's Q-test) and the $\mathrm{I}^{2}$ statistic to assess the fixed-effects assumption. The $\mathrm{I}^{2}$ index describes the percentage of total variability across studies due to true heterogeneity rather than 
chance, with a value of $>75 \%$ indicating medium-to-high heterogeneity [28]. If evidence of heterogeneity was found $\left(\mathrm{I}^{2}>75 \%\right)$, a meta-regression analysis (mixed-effects model) was subsequently performed to explore the sources of heterogeneity, using the logarithmic individual effect size for each trial as the outcome. The following mixed-effects model was used:

$\theta_{\mathrm{j}}=\gamma_{0}+\gamma_{1} \times \bmod +\mathrm{u}_{\mathrm{j}}+\varepsilon_{\mathrm{j}}$

where $\gamma_{0}$ is the expected effect for a study when the moderator is zero, $\gamma_{1}$ the fixed-effects, mod is the moderator introduced, $\mathrm{u}_{\mathrm{j}}$ the random-effects and $\varepsilon_{\mathrm{j}}$ the residuals.

Many models were reported in each publication, and choices had to be made regarding which models to retain in the dataset. Different models within a single paper were often based on the same cow-level raw data but differed in terms of moderators included (Table 1) in particular for metabolite and time of testing (NEFA, BHB, postpartum or prepartum) as well as frequency of testing. Because many models were reported in each publication and for part retained in the present meta-analysis, a variable class was created and used as random variable in the present mixed-effects models (details of the variable Class in Supplementary data).

For each of the outcomes of interest, forest plots were produced to show the effect sizes (logarithmic scale of risk) for each relevant studies with an overall summary estimate generated from the meta-analysis. Biased effect sizes for individual studies are an unfortunate possibility and therefore any biases in individual studies are likely to propagate into the overall summary measure. Publication bias that could for instance originate from high weight of one study on the meta-regression results was investigated for each meta-regression using funnel plots with residual value of effect size and a measure of study precision.

\section{Results}


The table 2 summarizes the studies included in the meta-analysis. The population included varied from 3 to 528 herds and from 213 to 5,884 cows. The studies referenced used cut-points ranging from 0.96 to $1.4 \mathrm{mmol} / \mathrm{L}$ for postpartum $\mathrm{BHB}$, from 0.33 to $1 \mathrm{mmol} / \mathrm{L}$ for postpartum NEFA and from 0.27 to $0.4 \mathrm{mmol} / \mathrm{L}$ for prepartum NEFA.

\subsection{Pregnancy at first insemination}

The association between elevated of NEFA and BHB and pregnancy at first insemination (P/AI) was reported in 9 models (Table S2) from 4 publications [16-17-29-22]. The raw risk (mean $\pm \mathrm{SD}$ ) of P/AI in cows with elevated NEFA and BHB was $0.604 \pm 0.195$. The heterogeneity of the data set was high $\left(\mathrm{I}^{2}=90,149 \%\right)$ and Q score was 81,210 on 8 degrees of freedom $(\mathrm{P}<0.0001)$. The intercept of logarithmic effect size in the randomeffects model (no moderator) was $-0.648(\mathrm{SE}=0.281 ; \mathrm{P}<0.05)$, corresponding to a risk of $0,52(95 \% \mathrm{CI}=0,30$ to 0.91$)$.

The inclusion of the moderator "Metabolite" $\left(\mathrm{Q}_{\text {Metabolite }}=41.62, \mathrm{P}<0.0001\right)$ reduced the heterogeneity by $12 \%$ (Table 3; Fig. 2) showing that the type of test (NEFA/BHB) actually influences the P/AI. The cows that experienced elevated post-partum circulating NEFA were $32 \%$ less likely to conceive at AI1 than cows classified as postpartum elevated circulating $\mathrm{BHB}(\mathrm{OR}=0.68)$. The risk for $\mathrm{P} / \mathrm{AI}$ of cows with high $\mathrm{BHB}$ was also 0.62 $(95 \% \mathrm{CI}=0.41-0.93)$. The moderator "Frequency of testing" was not significant and the related meta-regression was not kept. The inclusion of the moderator "Multivariable" $\left(Q_{\text {Multivariable }}=\right.$ 74.13, $\mathrm{P}<0.0001$ ) slightly reduced the heterogeneity (Table 3). The intercept of logarithmic effect size in the random-effects model adjusted by the moderator Multivariable was -0.69 $(\mathrm{SE}=0.27 ; \mathrm{P}<0.05)$, corresponding to a risk of $0.50(95 \% \mathrm{CI}=0.29-0.86)$. Because the metaregression adjusted by the moderator "Metabolite" allowed a higher reduction in heterogeneity, this regression was kept. There was no evidence to suggest publication bias in funnel plots for P/AI (fig. 1). 


\subsection{Estrous cyclicity}

The association between elevated of NEFA and BHB and estrous cyclicity was reported in 7 models from 2 publications [29-30]. The raw risk (mean \pm SD) of estrous cyclicity in cows with elevated NEFA or BHB was $0.991 \pm 0.466$. It was on average $0.682 \pm 0.383$ and $1.403 \pm$ 0.116 in cows above the threshold in either wk 1 or 2 or in one wk only, respectively (Table S3). The results reported alternatively increased (risk $>1$ ) or decreased risk $(<1)$ of estrus cyclicity in cases of high NEFA or BHB. This is in accordance with a very high heterogeneity of the data set $(\mathrm{I} 2=90 \%)$ with $\mathrm{Q}$ score of 47.524 on 6 degrees of freedom $(\mathrm{P}<0.0001)$. The intercept of logarithmic effect size in the fixed-effects regression with no moderator was $0.1281(\mathrm{SE}=0.232, \mathrm{P}<0.10)$, corresponding to a risk of $1.14(90 \% \mathrm{CI}=0.83-1.08)$. The random-effects and mixed-effects regressions were not significant.

\subsection{Time to pregnancy}

The HR for the time to pregnancy in cow with elevated of BHB and NEFA was reported in 6 models from 3 studies [1-2-6] ("meta" package). The heterogeneity of the data set was high $(\mathrm{I} 2=76.8 \%)$ and $\mathrm{Q}$ score was 21.590 on 5 degrees of freedom $(\mathrm{P}=0.0006)$. The pooled risk was 0.77 [95\% CI= 0.61-0.97] for the random-effects model. None of the moderators were significant and the meta-regression was not further considered. Raw data suggest that the heterogeneity comes from the very low values of the HR in [16] compared to the other 2 studies (Table S4). Excluding [16] showed a high decreased in heterogeneity: the HR for time to pregnancy from the random-effect models was then $0.84(95 \% \mathrm{CI}=0.77-0.92)$.

\subsection{Metritis and placental retention}

The association between elevated of NEFA and BHB and metritis was reported in 11 models (Table S5) from 6 publications [31-32-7-14-20-15]. The heterogeneity of the data set was low $(\mathrm{I} 2=9.4 \%)$ and $\mathrm{Q}$ score was 11.030 on 10 degrees of freedom $(\mathrm{P}=0.355)$. The raw mean risk was $3.49 \pm 4.29$ and the combined risk were calculated to be $1.91(95 \% \mathrm{CI}=1.72-2.12$, 
$\mathrm{P}<0.0001)$ and $1.912(95 \% \mathrm{CI}=1.70-2.15 ; \mathrm{P}<0.0001)$ for the fixed and random-effects models, respectively.

The association between elevated of prepartum NEFA and placental retention (Table S6) was reported in only 3 models from 3 publications [12-33-32], as it was in the previous metaregression [23]. No heterogeneity in the data set $(\mathrm{I} 2=25.1 \%)$ was found. The raw mean risk was 1.63 and the combined risk was calculated to be $1.47(95 \% \mathrm{CI}=1.22-1.79, \mathrm{P}<0.001)$ for the fixed-effects model and it was $1.51(95 \% \mathrm{CI}=1.19-1.92, \mathrm{P}=0.0006)$ for the random-effects model.

\section{Discussion}

The present meta-analysis study was conducted to describe the association of elevated concentrations of NEFA and elevated concentrations of BHB in transition dairy cow with reproductive performance and disorders. Despite the small number of epidemiologic studies on this subject, the database created by collation of eligible studies provided a new overview on this topic.

The result on P/AI, metritis and placental retention are in accordance with the previous meta-analysis [23]. For P/AI and metritis, a new study was available in each outcome and their inclusion allowed to strengthen the previous results. In the present work and in the previous meta-analysis [23], a low heterogeneity was found for metritis and placental retention but the heterogeneity was high for P/AI. The adjustments performed here thanks to the moderator "Metabolite" and "Multivariable" allowed to reduce the heterogeneity, although no moderator was found to reduce the heterogeneity in the previous meta-regression. The adjustment brought by the meta-regression on P/AI is in accordance with results showing that using postpartum NEFA concentrations resulted in a greater risk than using prepartum NEFA and postpartum BHB concentrations [31-30-19-29]. Blood NEFA concentrations have 
been found to be a more associated with health and production than BHB [9]. Yet the reference class retained in the present work was BHB since its measure in the field is really easier -with cow side tests- compared to NEFA. To sum up, the risk for P/AI in case of subclinical ketosis was 0.67 in the previous meta-regression. It was 0.52 in the present work in cases of no moderator, and it was 0.62 if test was performed with BHB only. These differences in the risk remain questionable since the threshold used for BHB and NEFA may have a bigger influence compared to the nature of the metabolite used (Annex) and the NEFA class only included 2 raw data. Moreover, the biological relevance of the results is also questionable since the differences in the risk remained low. To sum up, the present work suggests to consider a risk of $0.62(95 \% \mathrm{CI}=0.41$ to 0.93$)$ for $\mathrm{P} / \mathrm{AI}$ in case of high $\mathrm{BHB}$.

No meta-analysis on estrous cyclicity and time to pregnancy in case of high BHB or NEFA was available up to now. Unfortunately, the number of publications that quantify such an association are still rare and the heterogeneity between the studies was found to be high without any possibility to clearly adjust the risk by including moderators. Further, many of these studies used ovulation synchronization protocols and timed artificial inseminations. The time to first insemination or display of estrus were not useful indicators in these studies because these events were either scheduled or not measured [31]. For both outcomes two different groups of values of risk were found, and the meta-regression did not achieve to clearly fix this issue. This supports a high need of further studies to clearly address this point, especially as SCK is now a ubiquitous disorder. On the other hand, reproductive performance of dairy cows (which is important in worldwide) are deteriorating. For time to pregnancy, the exclusion of the study with very low values of risk [16] decreased the heterogeneity, but the reason why so different HR are found was not identified here. The HR of this study [18] were under 0.1 whereas the HR were above 0.8 for other ones (Table S4). For estrus cyclicity, the classes of the moderator "Frequency of testing" were "one" in one study [30] and "Either" in 
the second one [29], limiting any improvement in the understanding of the high heterogeneity in the present work (Table S3). Raw data with opposite sign of the risk, high heterogeneity without any possibility to reduce it and non-significant meta-regression $(\mathrm{P}=0.0507)$ suggest to conclude that no overview is possible at this stage on the association between estrus cyclicity and high NEFA or BHB. No other solution than more study may help in understanding the complex relationship between SCK and estrus cyclicity. Bias among management practices are likely to occur in these studies, with perhaps farmers changing their routines in the reproduction management for cows with subclinical ketosis. For instance, the fact that cyclicity was checked at 21 or 49 days postpartum and that the mean prevalence of cyclicity was $26.4 \%$ or $80.5 \%$, (Table S3) may contribute to the dominant $>1$ and $<1$ ORs observed in the 2 studies, respectively [30-29]. To sum up, the present work suggests to retain an HR of $0.77(95 \% \mathrm{CI}=0.61$ to 0.97$)$ for time to pregnancy in case of high BHB or NEFA, and no definitive results for estrus cyclicity.

The present meta-analysis was performed as recommended [27-34]. It gathered different expression of risk. The difference between the OR and RR generally remained low in the meta-analysis previously conducted [23]. Moreover, RR and OR can be considered interchangeable as a measure of the relative change in the risk of a preventable event [35]. RR and OR have very close values in cases of low prevalence of the outcome. In spite of efforts done in the present work, the reduction in the heterogeneity of the results was limited. Farm management practices such as the voluntary waiting period, estrus detection protocol or service protocol may differ between studies and contribute to the heterogeneity observed for some outcomes without any possibility to catch the heterogeneity by the available moderators.

The mechanisms underlying the association between high BHB and/or NEFA and reproductive disorders are still not fully understood. A deteriorated immune function is among other involved. Elevated NEFA concentration is detrimental to neutrophil functions 
and uterine health as well as puerperal metritis [13]. Furthermore, high plasma NEFA are directly linked with the development of oxidative stress and uncontrolled inflammatory responses [36]. In addition, high occurrence of metritis in ketotic cows may be explained by immunosuppression during the postpartum period. Leukocytes from naturally occurring ketotic cows have lower chemotactic differentials than those from non-ketotic cows, and chemotactic capacities impaired when leukocytes migrate in an environment with ketone bodies [37]. The relationship between fetal membrane expulsion and NEFA may be associated with the negative effect of NEFA on at least some aspects of immune function [38].

\section{Conclusions}

The present work allowed a new overview on the association between high BHB or NEFA and reproductive performance and disorders, thanks to a synthetic analysis of available results.

The risk for metritis and placental retention in case of high BHB or NEFA was close to previous results and was $1.91(\mathrm{IC} 95 \%=1.72-2.12)$ and $1.51(95 \% \mathrm{CI}=1.19-1.92)$, respectively. The present work also suggests to consider a risk for P/AI of 0.62 (95\%CI=0.41$0.93)$ in case of high BHB. The HR for time to pregnancy was $0.77(95 \% \mathrm{CI}=0.61-0.97)$ in case of high BHB and NEFA. The present meta-analysis failed to clearly conclude on the association between estrus cyclicity and high BHB or NEFA. It highlights the dramatic need of further intensive epidemiologic studies on the link between hyperketonemia and reproductive performance. 


\section{References}

[1] VandeHaar M.J and St-Pierre N. Major Advances in Nutrition: Relevance to the Sustainability of the Dairy Industry. J. Dairy Sci. 2006; 89:1280-1291.

[2] Drackley JK, Overton T R, Douglas GN. Adaptations of glucose and long chain fatty acid metabolism in liver of dairy cows during the periparturient period. J. Dairy Sci. 2001; 84 (Suppl.), E100-E112.

[3] Kokkonen T, Taponen J, Anttila T, Syrjala-Qvist L, Delavaud C, Chillard Y et al. Effect of body fatness and glucogenic supplement on lipid and protein mobilization and plasma leptin in dairy cows. J. Dairy Sci. 2005; 88:1127-1141.

[4] Lassen ED, Fettman MJ. Laboratoty evaluation of lipids. In: Thrall, M.A, Baker, D.C, Campbell, T.W, DeNicola, D, Fettman, M.J, Lassen, E.D, Rebar, A, Weiser, G. (Eds.), Veterinary Hematology and Clinical Chemistry. Lippincott Williams \& Wilkins, Baltimore, MD, USA; 2004, p. 421-431.

[5] Drackley JK, Andersen JB. Splanchnic metabolism of long-chain fatty acids in ruminants. In: Ruminant Physiology: Digestion, Metabolism and Impact of Nutrition on Gene Expression, Immunology and Stress. Academic Publishers, Wageningen, The Netherlands; 2006, p. 199-224.

[6] Nielsen NI, Ingvartsen KL. Propylene glycol for dairy cows. A review of the metabolism of propylene glycol and its effects on physiological parameters, feed intake, milk production and risk of ketosis. Anim. Feed Sci. Technol 2004; 115: 191-213.

[7] Duffield TF, Lissemore KD, McBride BW, Leslie K. Impact of hyperketonemia in early lactation dairy cows on health and production. J. Dairy Sci. 2009; 92:571-580.

[8] Weng X, Zhao W, Neethirajan S, Duffield TF. Microfluidic biosensor for $\beta$ Hydroxybutyrate $(\beta \mathrm{HBA})$ determination of subclinical ketosis diagnosis. J Nanobiotechnology 2015; 13:13.

[9] McArt JAA, Nydam DV, Oetzel GR, Overton TR, Ospina PA. Elevated non-esterified fatty acids and b-hydroxybutyrate and their association with transition dairy cow performance. Vet J 2013;198: $560-570$.

[10] Ospina PA, McArt JAA, Overton TR, Stokol T, Nydam DV. Using Nonesterified Fatty Acids and b-Hydroxybutyrate Concentrations During the Transition Period for Herd-Level Monitoring of Increased Risk of Disease and Decreased Reproductive and Milking Performance. Vet Clin North Am Food Anim Pract 2013. 29(2): 387-412

[11] Dohoo IR, Martin SW. Subclinical ketosis: prevalence and association with production and disease. Can. J. Comp. Med 1984; 48:1-5.

[12] LeBlanc SJ, Herdt T, Seymour W, Duffield T, Leslie K. Factors associated with peri-partum serum concentrations of vitamin $\mathrm{E}$, retinol, and $\beta$-carotene in Holstein dairy cattle, and their associations with periparturient disease. J Dairy Sci 2004; 87: 609-619.

[13] Hammon DS, Evjen IM, Dhiman TR, Goff JP, Walters JL. Neutrophil function and energy status in Holstein cows with uterine health disorders. Vet Immunol Immunopathol 2006; 113:21-9. 
[14] Dubuc J, Duffield TF, Leslie KE, Walton JS, LeBlanc SJ. Risk factors for postpartum uterine diseases in dairy cows. J. Dairy Sci 2010; 93 :5764-5771.

[15] Shin EK, Jeong JK, Choi IS, Kang HJ, Hur TY, Jung YH, Kim IH. Relationships among ketosis, serum metabolites, body condition, and reproductive outcomes in dairy cows. Theriogenology 2015; 84:252-260.

[16] Walsh RB, Walton JS, Kelton D, LeBlanc SJ, Leslie KE, Duffield TF. The Effect of Subclinical Ketosis in Early Lactation on Reproductive Performance of Postpartum Dairy Cows. J. Dairy Sci 2007; 90:2788-2796.

[17] McArt JAA, Nydam DV, Oetzel GR. Epidemiology of subclinical ketosis in early lactation dairy cattle. J. Dairy Sci 2012; 95 :5056-5066.

[18] Ospina PA, Nydam DV, Stokol T, Overton TR. Associations of elevated nonesterified fatty acids and $\beta$-hydroxybutyrate concentrations with early lactation reproductive performance and milk production in transition dairy cattle in the northeastern United States. J. Dairy Sci 2010a; 93 :15961603.

[19] Garverick HA, Harris MN, Vogel-Bluel R, Sampson JD, Bader J, Lamberson WR et al. Concentrations of nonesterified fatty acids and glucose in blood of periparturient dairy cows are indicative of pregnancy success at first insemination. J. Dairy Sci 2013; $96: 181-188$.

[20] Suthar VS, Canelas-Raposo J, Deniz A, Heuwieser W. Prevalence of subclinical ketosis and relationships with postpartum diseases in European dairy cows. J. Dairy Sci 2013; $96: 1-14$.

[21] Vanholder T, Papen J, Bemers R, Vertenten G, Berge ACB. Risk factors for subclinical and clinical ketosis and association with production parameters in dairy cows in the Netherlands. J. Dairy Sci 2015; 98 (2):880-888.

[22] Rutherford AJ, Oikonomou G, Smith RF. The effect of subclinical ketosis on activity at estrus and reproductive performance in dairy cattle. J. Dairy Sci 2016; 99 (6):4808-4815.

[23] Raboisson D, Mounié M, Maigné E. Diseases, reproductive performance, and changes in milk production associated with subclinical ketosis in dairy cows: A meta-analysis and review. J. Dairy Sci 2014; 97 :7547-7563.

[24] R Development Core Team. R: A language and environment for statistical computing. R Foundation for Statistical Computing, Vienna, Austria. ISBN 3-900051-07-0. URL https://www.Rproject.org/. 2015.

[25] Schwarzer G. meta: Meta-Analysis with R. R package version 1.1-8. 2010. URL http://CRAN.Rproject.org/package=meta.

[26] Viechtbauer W. metafor: Meta-Analysis Package for R. R package version 1.0-1. 2010. URL http://CRAN.R-project.org/package=metafor.

[27] Viechtbauer Wb. Conducting Meta-Analyses in R with the metaphor Package. J Stat Softw 2010; 36 (3): $1-48$.

[28] Huedo-Medina TB, Sánchez-Meca J, Marín-Martínez F, Botella J. Assessing heterogeneity in meta-analysis: Q statistic or I2 index? Psychol Methods 2006; 11(2): 193-206. 
[29] Ribeiro ES, Lima FS, Greco LF, Bisinotto RS, Monteiro APA, Favoreto M, et al. Prevalence of periparturient diseases and effects on fertility of seasonally calving grazing dairy cows supplemented with concentrates. J. Dairy Sci 2013; $96: 1-16$.

[30] Dubuc J, Duffield TF, Leslie KE, Walton JS, LeBlanc SJ. Risk factors and effects of postpartum anovulation in dairy cows. J. Dairy Sci 2012; 95 :1845-1854.

[31] Ospina PA, Nydam DV, Stokol T, Overton TR. Evaluation of nonesterified fatty acids and $\beta$ hydroxybutyrate in transition dairy cattle in the northeastern United States: Critical thresholds for prediction of clinical diseases. J. Dairy Sci 2010b; 93 :546-554.

[32] Chapinal N, Carson M, Duffield TF, Capel M, Godden S, Overton M et al. The association of serum metabolites with clinical disease during the transition period. J. Dairy Sci 2011; 94 :4897-4903.

[33] Quiroz-Rocha GF, LeBlanc SJ, Duffield TF, Wood D, Leslie KE, Jacobs RM. Evaluation of prepartum serum cholesterol and fatty acids concentrations as predictors of postpartum retention of the placenta in dairy cows. J. Am. Vet. Med. Assoc 2009; 234:790-793.

[34] Schwarzer G, Carpenter JR, Rücker G. MetaAnalysis with R. edition Springer International Publishing Switzerland; 2015, P. 85-104.

[35] Scott I. Interpreting risks and ratios in therapy trials. Aust Prescr 2008; 31:12-6.

[36] Sordillo LM, Raphael W. Significance of Metabolic Stress, Lipid Mobilization, and Inflammation on Transition Cow Disorders. Vet Clin North Am Food Anim Pract 2013; 29 (2):267-278.

[37] Holtenius K, Wallerc KP, Essén-Gustavssone B, Holtenius P, Sandgren CH. Metabolic parameters and blood leukocyte profiles in cows from herds with high or low mastitis incidence. The Veterinary Journal 2004;168 (1): 65-73.

[38] Lacetera N, Scalia D, Bernabucci U, Ronchi B, Pirazzi D, Nardone A. Lymphocyte Functions in Overconditioned Cows Around Parturition. J. Dairy Sci 2005; 88 (6): 2010-2016. 
Table 1. Definition of the moderators included in the meta-regressions

\begin{tabular}{|l|l|l|}
\hline Moderator & Value & Description \\
\hline Metabolite & BHB-post & High post-partum BHB \\
\cline { 2 - 3 } & NEFA-post & High post-partum NEFA \\
\hline Frequency of testing & Both & High BHB or NEFAs in wk 1 and in wk 2. \\
\cline { 2 - 3 } & One & High BHB or NEFAs in one fixed time (wk-1, wk1 or \\
\cline { 2 - 3 } & Either & wk2) \\
\hline Multivariate & & High BHB or NEFAs in either of the first 2 wk \\
& Univariable & No co-variable in the model \\
\cline { 2 - 3 } & Multivariable & At least one co-variable in the model \\
\hline
\end{tabular}

1: The categories BHB-pre and NEFA-pre were not retained since the situations was not faced in the present work 
Table 2. Description of each study included in the meta-analysis.

\begin{tabular}{|c|c|c|c|c|c|c|c|c|c|}
\hline Study & Origin $^{1}$ & $\begin{array}{l}\text { Type } \\
\text { of } \\
\text { study }^{2}\end{array}$ & $\begin{array}{l}\text { \# of } \\
\text { herds }\end{array}$ & $\begin{array}{l}\# \text { of } \\
\text { cows }\end{array}$ & $\begin{array}{l}\text { Time of } \\
\text { sampling }\end{array}$ & $\begin{array}{l}\text { Metaboli } \\
\text { te }\end{array}$ & $\begin{array}{l}\text { Cut- } \\
\text { point }\end{array}$ & $\begin{array}{l}\text { Subclinical } \\
\text { ketosis } \\
\text { prevalence } \\
(\%)\end{array}$ & $\begin{array}{l}305 \mathrm{~d} \text { milk } \\
\text { production }(\mathrm{kg})\end{array}$ \\
\hline LeBlanc et [12] & $\mathrm{CA}$ & $\mathrm{Ct}$ & 20 & 138 & $\begin{array}{l}4 \text { to } 10 \\
\text { DPEC }\end{array}$ & NEFA & 0.5 & NA & NA \\
\hline Walsh et al. [16] & $\mathrm{CA}$ & $\mathrm{Ct}$ & 25 & 796 & $\begin{array}{l}21 \text { DPEC } \\
\text { and } 7 \text { to } \\
63 \text { DIM }\end{array}$ & BHB & 1 to 1.4 & $13-42$ & 7,000 to 10,000 \\
\hline Duffield et al. [7] & US & Obs & 25 & 1,010 & 1-14 DIM & BHB & 0.6 to 2 & NA & $\begin{array}{l}8,211.5 \pm 201.4 \\
\text { to } 8,639.2 \\
\pm 195.2 \\
\end{array}$ \\
\hline $\begin{array}{l}\text { Quiroz-Rocha et al. } \\
\text { [33] }\end{array}$ & $\mathrm{CA}$ & $\mathrm{Ct}$ & 20 & 990 & $\begin{array}{l}7 \text { to } 1 \\
\text { DPEC }\end{array}$ & NEFA & 0.3 & NA & NA \\
\hline \multirow[t]{2}{*}{ Dubuc et al. [14] } & \multirow[t]{2}{*}{ US, CA } & \multirow[t]{2}{*}{ Obs } & \multirow[t]{2}{*}{3} & \multirow[t]{2}{*}{1,363} & $\begin{array}{l}7 \text { to } 1 \\
\text { DPEC }\end{array}$ & NEFA & $\begin{array}{l}0.6 \text { to } \\
1.1\end{array}$ & \multirow[t]{2}{*}{17} & \multirow[t]{2}{*}{ NA } \\
\hline & & & & & $\begin{array}{l}1 \text { to } 21 \\
\text { DIM }\end{array}$ & BHB & $1.3-1.5$ & & \\
\hline \multirow[t]{2}{*}{ Ospina et al. [18] } & \multirow[t]{2}{*}{ US } & \multirow[t]{2}{*}{ Obs } & \multirow[t]{2}{*}{91} & \multirow[t]{2}{*}{2290} & \multirow{2}{*}{$\begin{array}{l}14-2 \\
\text { DPEC and } \\
3-14 \text { DIM }\end{array}$} & NEFA & $\begin{array}{l}0.33 \text { to } \\
0.72\end{array}$ & NA & \multirow[t]{2}{*}{$\begin{array}{l}12,197 \text { and } \\
12,572\end{array}$} \\
\hline & & & & & & $\mathrm{BHB}$ & $0.7-1.2$ & NA & \\
\hline \multirow[t]{2}{*}{ Ospina et al. [31] } & \multirow[t]{2}{*}{ US } & \multirow[t]{2}{*}{ Obs } & \multirow[t]{2}{*}{100} & \multirow[t]{2}{*}{2758} & \multirow{2}{*}{$\begin{array}{l}14-2 \\
\text { DPEC and } \\
3-14 \text { DIM }\end{array}$} & NEFA & $\begin{array}{l}0.2 \text { to } \\
1.02 \\
\end{array}$ & \multirow[t]{2}{*}{ NA } & \multirow[t]{2}{*}{ NA } \\
\hline & & & & & & BHB & $\begin{array}{l}0.8 \text { to } \\
1.4\end{array}$ & & \\
\hline Chapinal et al. [32] & US, CA & Obs & 55 & 2,365 & $\begin{array}{l}10-4 \\
\text { DPEC and } \\
1 \text { to } 21 \\
\text { DIM } \\
\end{array}$ & NEFA & $\begin{array}{l}0.3 \text { to } \\
1.0\end{array}$ & 26 & NA \\
\hline Dubuc et al. [30] & $\mathrm{US}, \mathrm{CA}$ & Obs & 6 & 2134 & $\begin{array}{l}7 \text { DPEC } \\
\text { and } \\
1 \text { to } \\
21 \text { DIM }\end{array}$ & NEFA & $0.4-0.9$ & 17 & $11,571 \pm 2,437$ \\
\hline McArt et al. [17] & US & Obs & 3 & 751 & $\begin{array}{l}3-16 \\
\text { DIM }\end{array}$ & BHB & 1.20 & 20 & NA \\
\hline \multirow[t]{2}{*}{ Ribeiro et al. [29] } & \multirow[t]{2}{*}{ US } & \multirow[t]{2}{*}{ Obs } & \multirow[t]{2}{*}{69} & \multirow[t]{2}{*}{771} & \multirow[t]{2}{*}{ 7-14 DIM } & NEFA & 0.70 & 20.0 & \multirow[t]{2}{*}{$\approx 6,000$} \\
\hline & & & & & & BHB & 0.96 & 35.4 & \\
\hline Suthar et al. [20] & EU & Obs & 528 & 5,884 & 2-15 DIM & BHB & $\begin{array}{l}1.2 \text { to } \\
1.4 \\
\end{array}$ & 21.8 & NA \\
\hline Shin et al. [15] & SK & Obs & 4 & 213 & 7-14 DIM & BHB & 1.20 & 27.7 & NA \\
\hline Rutherford et al. [2] & UK & Obs & 3 & 203 & 7-21 DIM & BHB & 1.20 & 17 & $10,128 \pm 1,478$ \\
\hline
\end{tabular}

${ }^{1}$ Origin: US = United States; $\mathrm{CA}=$ Canada; EU= Europe; SK=South Korea; UK=United Kingdom.

${ }^{2}$ Obs: Observational study, Ct: Clinical trial.

${ }^{3}$ DPEC, days prior to expected calving; DIM, days in milk. 
Table 3. Results from meta- regression of the effects of elevated NEFAs and BHB on P/AI, estrous

cyclicity, time to pregnancy, metritis and

\begin{tabular}{|c|c|c|c|c|c|c|c|c|}
\hline & \multicolumn{2}{|c|}{ Descriptive statistics } & \multicolumn{2}{|c|}{ Meta-regression } & \multirow[b]{2}{*}{$\begin{array}{l}\mathrm{I}^{2} \\
(\%)\end{array}$} & \multirow[b]{2}{*}{ Q (df) } \\
\hline & & & $\mathrm{n}$ & $\begin{array}{l}\text { Mean value of } \\
\text { risk (SD) }\end{array}$ & Risk & $95 \% \mathrm{CI}$ & & \\
\hline \multirow[t]{7}{*}{ P/AI } & \multicolumn{2}{|c|}{ No moderator } & 9 & $0.604(0.195)$ & $0,52^{1} * * *$ & $0,301-0,908$ & 90 & $81,2(8) * * *$ \\
\hline & Model 1 & Intercept & - & - & $0,62^{1} * * *$ & $0,413-0,930$ & \multirow[t]{3}{*}{83} & \multirow[t]{3}{*}{$41,6(7) *$} \\
\hline & & Test $=$ NEFA & 2 & $0.495(0.025)$ & $0,68 * *$ & $0,529-0,872$ & & \\
\hline & & Test $=$ BHB & 7 & $0.636(0.211)$ & \multicolumn{2}{|l|}{ Referent } & & \\
\hline & Model 2 & Intercept & - & - & $0,50^{1} * * *$ & $0,291-0,859$ & \multirow[t]{3}{*}{90} & \multirow[t]{3}{*}{$74,1(7) *$} \\
\hline & & Model $=\mathrm{U}$ & 3 & $0.673(0.054)$ & $1,24 *$ & $1,034-1,481$ & & \\
\hline & & Model=M & 6 & $0.570(0.229)$ & \multicolumn{2}{|l|}{ Referent } & & \\
\hline Estrous cyclicity & \multicolumn{2}{|c|}{ No moderator } & 7 & $0.991(0.466)$ & $1.14^{2 \prime \prime}$ & $0.99-1.29^{3}$ & 87 & $47.7(6) * * *$ \\
\hline Time to pregnancy & \multicolumn{2}{|c|}{ No moderator } & 6 & $0.590(0.376)$ & $0.77^{1 *}$ & $0.611-0.972$ & 76 & $21.5(5) * *$ \\
\hline Metritis & \multicolumn{2}{|c|}{ No moderator } & 11 & $3.495(2.298)$ & $1.91^{1 * * *}$ & $1.70-2.15$ & 9 & $11.0(10)$ \\
\hline Placental retention & \multicolumn{2}{|c|}{ No moderator } & 3 & $1.633(0.235)$ & $1.51^{1} * *$ & $1.19-1.92$ & 25 & $2.6(2)$ \\
\hline
\end{tabular}

$* * * \mathrm{P}<0.0001 ; * * \mathrm{P}<0.001 ; * \mathrm{P}<0.05 ; " \mathrm{P}<0.10$

1 Random-effects model (no moderator) or mixed-effects model

2 Fixed-effects model

$390 \% \mathrm{CI}=0.83-1.08$ 


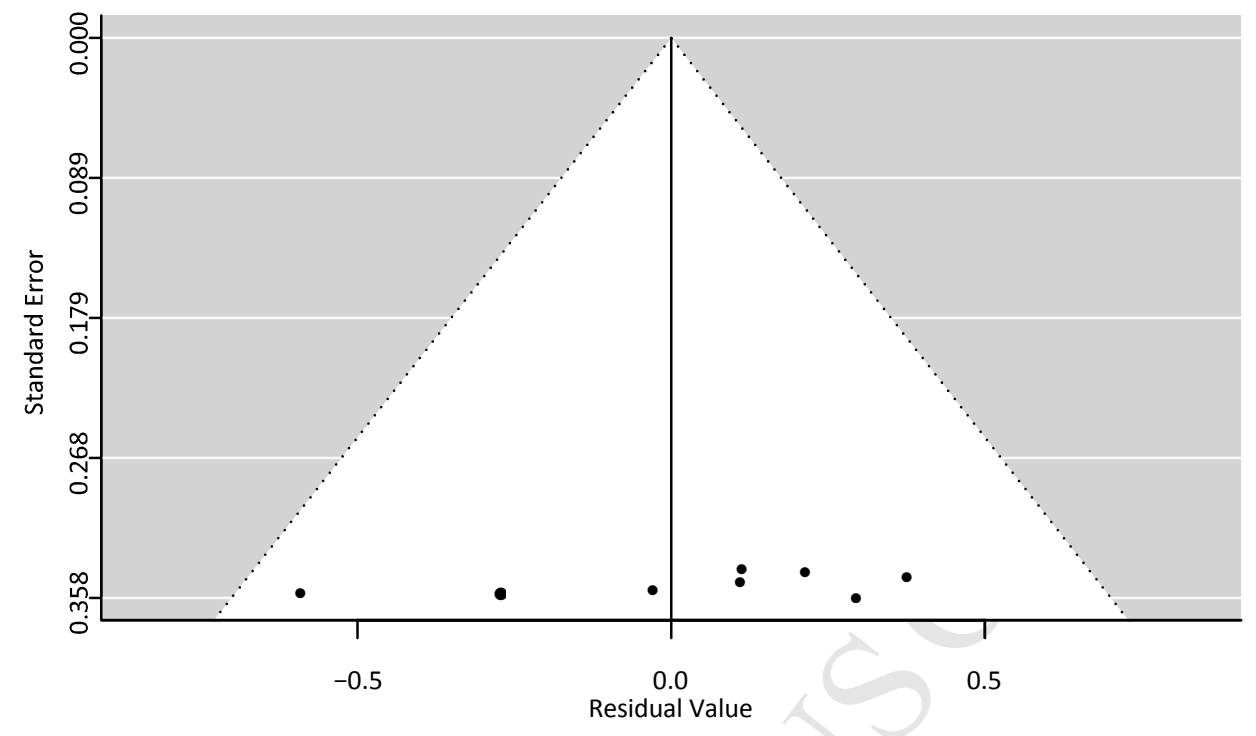

Fig. 1. Funnel plots to assess possible publication bias corresponding to meta-regression performed for the effect of elevated BHB and NEFA on P/AI. 


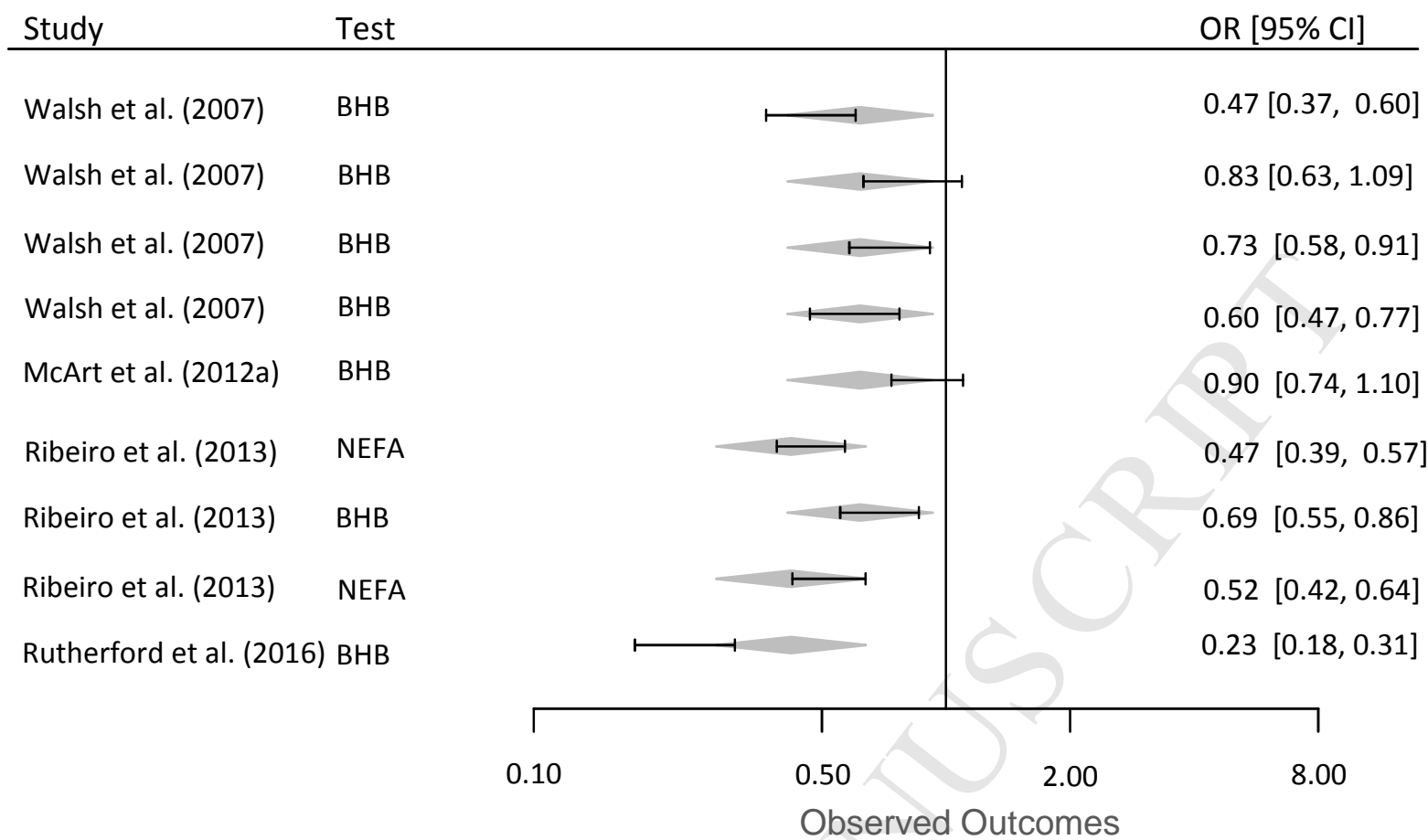

Fig. 2. Forest graph for Forest graph for P/AI. Adjustments were made for the moderator "Metabolite".

The gray diamonds represent the logarithmic effect size adjusted for the BHB-post or NEFA-post models. 


\section{Highlights}

1. Overview on the association between high BHBA or NEFA and reproductive performance.

2. Failure to conclude on the association between estrus cyclicity and high BHBA or NEFA.

3. Need of further epidemiologic studies on this topic. 